\title{
Doing Nation in Empires: The Emergence of Turkey and Austria
}

\author{
Kevser Muratović and Florian Gimpl \\ University of Vienna
}

\section{Abstract}

This article examines nation-building in relation to education and educational institutions, taking two former big players in European politics in the wake of the First World War as examples: the Ottoman Empire and the Habsburg Empire. The Habsburg Empire is examined by focusing particularly on textbooks around and after 1918, comparing them with each other and understanding them as major tools for spreading national ideas within state school. As will be shown, the idea of an Austrian nation can hardly be found, neither before nor immediately after the break of 1918, in the sense of the ideology of a nation-state. On the other hand, the Ottoman Empire is being examined as an example for doing nation in a process of transformation of social structures within non-western societies through western-style schools, thus contributing to nationally substantiating the Republic of Turkey. This article examines the imperial foundations of these two nation-states and how they and the preceding empires dealt with the modern concept of nation and nationalism.

Key words: Austria; Habsburg Empire; nation-building; Ottoman Empire; Turkey.

\section{Introduction}

The year 1918 saw not only the end of the First World War, but also „The Age of Empire" and with it the so-called "long nineteenth century" (Hobsbawm, 1989, p. 6). Eventually, the old European empires ceased to exist and were replaced by plenty of newly constructed nation-states on their former territories. In the struggle for a dominant cultural thesis about commonality and togetherness, the ideology of nationalism gained more and more intelligibility throughout the nineteenth century and eventually ruled out the imperial structures by the end of the First World War: the Russian Empire, the Ottoman Empire and the Habsburg Monarchy could not assert themselves against the ideology of nationalism. Within these nation-building processes, the enforcement of mass education played a crucial role and a centralized and standardized education system became a sine qua non (Tröhler, 2020), as has been 
carefully researched for several nation-states, e.g. France (Weber, 1979; Harp, 1998). The fusion of a nation as a cultural thesis of a "we" with the political power structure of a modern state creates a symbiosis of mutual reinforcement. Whereas the nation finally gains the administrative and organizational means to promote, and especially, to reproduce its dominant cultural thesis, the state gains legitimization for the exercise of power by citizens identifying themselves with this national "we". Schooling plays a crucial role within this symbiosis since it displays the site where the state provides the institutional basis for the fabrication of the national citizen, being able to "read" and understand the national symbols, rituals and beliefs. The successful amalgamation of nation and state within the last 200 years has rendered the construct of a nation-state so natural, making usage of the in fact different terms of nation, state, and nationstate nearly interchangeable. However, looking into the cases of the Ottoman as well as Habsburg Empires points out that, back in history, strong states, not within a national, but within an imperial context existed, uniting different cultural theses about belonging, inclusion, and exclusion within a shared territory. Therefore, this article offers a view of history that may seem strange in today's seemingly natural logic of the nation-state by tracing vanished models of two multi-ethnic, multi-lingual, and multi-denominational empires, that had (at least originally) strong state structures. Although the two cases have a strong state in common, their paths towards a singular national identity were quite different; for example, one managed to exist until the 1920s, refusing to merge into one particular national identity. Yet, both cases were also consistent in that their different development paths depended on their bourgeois elites.

Therefore, the aim of this article is to shed light on the interconnection of nationbuilding and education in imperial contexts. In order to do this, we understand nationalism according to Özkırımlı as a kind of discourse that has to be reproduced constantly to gain intelligibility and a kind of naturalness, thereby turning it into something that is taken for granted (Özkırımll, 2010, pp. 206-217). We further draw on the conceptual approaches regarding "nation","nation-states", "state" and "doing nation" that were proposed in the introduction of this issue (see article by Daniel Tröhler, in this issue). Rather than being a case study based on own archival research, this article wants to elucidate how imperial state functionings and societies altered successively in the course of the long nineteenth century by travelling ideas. Since we rely methodically on discourse-analytical research literature we subscribe to this methodology by conducting a content analysis of that literature. In order to do so we want to proceed in three steps: first, we want to unravel the nationalized perception of empires by setting out imperial state-society relations. Then, we want to look into how these imperial functionings were contested considering the ideology of nationalism. Thirdly, we want to pin down the performativity of the concept of nationalism while looking into how, and especially in which social spaces the identity, spatial, and historical claims (Özkırımlı, 2010, p. 51) emerged and developed within the Ottoman Empire and the Habsburg Empire. 


\section{Nation-states vs. empire-states}

Research based on the modernization paradigm often renders imperial models as ancient, pre-modern and traditional, describing them as ill-suited and not viable in an industrialized and modern world (Ahmad, 1993). Regarding the Ottoman Empire, Olivier Bouquet gave a detailed overview about such research culminating in a doxa according to which modernization can be equated to westernization that cannot be achieved except by modernizing state institutions (Bouquet, 2015). The related epistemology of development creates a binary construction of modern-developedindustrialized versus premodern-undeveloped-agrarian, whereas the model of an empire is ascribed to the latter in order to diagnose its condition and thus any need for action (Lewis, 2002a; Lewis, 2002b). Therefore, the emergence of nationalism and hence also of nation-states is often regarded as and researched in terms of fulfilling a natural, inevitable and sound path towards progress. But, as research has shown, different contexts create different sorts of nationalisms (Özkırımlı, 2010). In some cases, belonging to a nation refers more to a common spoken language, as it is in France; in other cases, ethnicity is coming to the forefront, like in Germany; and in yet another case, it is a shared history and political attitude, like in Switzerland. The emphasis placed on one of these elements is changeable throughout time. For instance, Finnish nationalism first relied on language to emphasize its separateness from Sweden, but afterwards, to cut itself off from Russian influence, a political vision was emphasized (Ichijo, 2013, p. 70). Nevertheless, the ability to connect to already existing cultural, linguistic, and ethnic bonds seems to be inevitable in the formation of nations (Smith, 2009). So, what could the cultural theses of the Ottoman and Austro-Hungarian Empires have been since they were multi-ethnic, multilingual and multi-denominational? To answer this question apart from modernization theories, we firstly want to separate the terms of state and nation from each other. Veronika Maricic has shown that the presupposed synthesis of nation and state does not work for the Scottish case (see article by Veronika Maricic, in this issue), challenging the fusion that has become as natural and self-evident as the concept of nationalism itself (Tröhler, 2020). This "nationalist perception" (Tröhler, 2020, p. 4) of the state obstructed the view on empires in the long nineteenth century. These empires had indeed strong state systems, constituting an important context for shaping everything that followed. Both of the investigated empires had indeed been strong imperial states linked to not just one particular nation but many different nations.

From the very beginning, the Ottoman state named itself "Devlet-i Aliyye”, which means nothing other than "The Sublime State" (Inalcik, 2014). The fact that even the Ottoman dynasty referenced their legitimacy to a state system shows the importance and meaning of this power structure. The traditionally strong attachment of Ottoman officials to their devlet (state) provided the basis for the development of different cultural theses about belonging and togetherness in the nineteenth century, ranging 
from Ottomanism to Turkish nationalism (Mardin, 1997, p. 117). On the way from empire to nation-state, it was exactly this existence of the empire-made "state-society" to which the republican founding fathers could resort (Meeker, 2001, p. 13). Ottoman governance techniques were shaped by a highly diversified population on a vast territory comprising European, Asian, and African lands, and with a long Byzantine-Greekruled history. Within its territory, the Ottoman state united Muslims from different cultural backgrounds, as well as Orthodox Armenians and Greeks, not to forget a Jewish minority. The fact that $40 \%$ of the Ottoman population around 1880 consisted of non-Muslims shows the rootedness and long-term experience of a multi-ethnic empire (Shaw \& Shaw, 1977, p. 240). The Ottoman Empire had in fact three societal arenas: the decentralized millet system, the Ottoman household system, and the four social-economic "estates" (Karpat, 2002, p. 330) that existed beyond religious identities.

The first arena was the millet system through which the Ottoman state tried to organize its above-mentioned heterogeneity. It was a system that was based on a commonly shared economic, social and political ground, while still preserving religious and ethno-cultural identity within the different millet groups. This blend of shared socioeconomic fields in conjunction with separated identities "Ottomanized" its society in a certain way. This circumstance was difficult to classify for Western observers, then just as now, as Kemal Karpat (2001) stated:

It is quite understandable, therefore, why Westerners who traveled through the Ottoman domains in the seventeenth and eighteenth centuries found sharp differences of customs, language, and religion among various regions and communities, but also observed that they were similar in economic, social and political outlook. (p. 617)

Michael Meeker also found, during his historiographic and ethnographic research on the north-eastern coast of Turkey, that Islamic sociability constituted the frame within which the heterogeneous imperial society had acted and felt attached to each other as well as to the Ottoman state (Meeker, 2001, p. 74). But how should one imagine this imperial state diverging from our national framed understanding? Until the beginning of the nineteenth century, the state had not been acting in a centerperiphery logic. This logic categorizes the strength of state influence according to a centers' direct access to the peripheries, thus rendering strong provincial powers as a possible outcome of a weak central government (Meeker, 2001). Rather, the center and the periphery were connected through a hub-and-spoke network, negotiating across cultures and social formations "by focusing on the multivalent, networked, vertical, and horizontal linkages and the malleable compacts established between state and social actors" (Barkey, 2008, p. 6). In this way, the Ottomans construed a form of governance that combined centralism and regionalism, consistency and flexibility of boundaries as well as the integration and toleration of diversity and dissent (Barkey, 2008, p. 29), thus incorporating semi- and unofficial local oligarchies, provincial nobles and social 
networks. Benjamin Gourisse stated that this hybrid specificity of the Ottoman state was and still is misinterpreted in terms of analyzing its functioning since most research overlooks that "the imperial system thus constitutes a 'feedback loop between societies [...] and institutions,' operating in a rhizomatic fashion" (Gourisse, 2015, p. 9).

To avoid misleading interpretations of Ottoman history being captured in a certain linguistic, and thus epistemological frame, Marc Aymes proposes using indigenous words in order to understand another social and political reality not necessarily corresponding with our own (Aymes, 2015, p. 30). Following this proposal, the Ottoman household system has to be mentioned as the second arena, since it was this specific organizational structure of Ottoman society that contributed to a different state-society relation from the founding in the fourteenth century until the beginning of the long nineteenth century. The household system constituted the power and reproduction site of the empire, whereby the sultanic household displayed a template for Ottoman governors, nobles, and officials.

It focuses on the sultan's household as the basic organizational unit of Ottoman society, a unit that cuts across formal institutional and class boundaries and contains within it the diverse activities of economic production, religious observance, political administration, and domestic affairs. This household, ranging in size from a hundred to thousands of members symbolically residing under one roof, comprises kin, retainers, and servants, all drawn from different segments of society. (Göcek, 1996, p. 18)

The third societal arena was the division of socio-economics into four estates (rulers, scribes, merchants, peasants) regardless of faith: there was no differentiation between a Muslim peasant and a Christian one, they were both part of the same estate. This societal structure avoided the emergence of an inherited aristocracy able to accumulate great wealth and thereby challenge the state and was instead meritocratic in its origins (Karpat, 2001, p. 311).

However, in the course of the eighteenth and nineteenth centuries, imperial state policies founded on decentralization and diversity came under heavy pressure and could no longer maintain the social differentiation of its millet nor its household structure. Due to a mixture of macro historical reasons like the influx of capitalism (Erimtan, 2008, p. 48), which especially increased the social mobility of non-Muslim lay people; war; the inflow of Muslim refugees from Russia as well as the rumbling Balkans (Shaw \& Shaw, 1977, p. 115), the Ottoman government looked to the West for political solutions. The standardization and accumulation of power in the center mixed with a capitalist logic (Keyder, 1997, p. 33) observed in their European neighbors were regarded as successful tracks towards strengthening the state (Barkey, 2008, p. 265). Formerly based on differentiation and plurality, the Ottoman state began to opt for centralization and homogenization as the 1829 clothing regulation of Sultan Mahmud II made evident. According to this regulation, former clothing laws demarcating social 
groups regarding occupation, rank, or religious affiliation were abolished, whereas a uniform for state officials was determined. A telling circumstance was that the new state servants' look - a fez (Ottoman headgear) combined with a European suit became the norm for all male subjects (Quataert, 2005, p. 144).

Similarly, the Habsburg Empire - for centuries, the direct neighbour and rival of the Ottoman Empire - can be seen as a strong state, either as a confederation or as a federal state. Austria-Hungary (1867-1918) succeeded the Austrian Empire (18041867) that was itself the heritage of the Holy Roman Empire, which was dissolved in 1806 by its last emperor, Franz II. Franz dissolved the empire because he feared that Napoleon, who had crowned himself Emperor of the French in 1804, would try to conquer the Holy Roman Empire and make himself the emperor of it. First and foremost, Napoleon, together with his regime, spread the idea of nationalism across Europe, leading to several German states defecting from the empire (Vocelka, 2000, pp. 170-172). Habsburg possessions contained peoples of various languages and cultural backgrounds after the recapture of south-eastern European territories from the Ottoman Empire in the aftermath of the failed Ottoman siege of Vienna in 1683. The reforms of Maria Theresia in the middle of the eighteenth century helped to develop a modern, strong, centralized state with Vienna as its capital and royal residence. These reforms also included various innovations in the educational system, like the introduction of compulsory basic schooling for girls and boys in 1774 (Vocelka, 2000, pp. 158-160). In that sense, the modernized and relatively centralized state was not less multi-ethnic, multi-denominational, and multi-lingual than the Ottoman Empire. Compulsory basic education was provided in the local language (e.g. Czech, Polish, German, Hungarian, etc.) which made it effective but difficult to control by the ministry. Thus, the originally Swiss-native House of Habsburg was obliged to use the German language and culture, but multi-lingualism was a matter of course for the members of the House, the nobility, and bourgeoisie, and rather widespread. Emperor Joseph II (1741/65-1790) advanced German as the official language for administration, primarily in the service of centralizing the state. But within a few years after that, the French Revolution and the Coalition Wars swept away France's Ancien Régime; and in the second half of the nineteenth century, Germany and Italy became nation-states to the disadvantage of the Austrian Habsburgs. It seemed that the Age of Empires was over and the "Age of Nation-states" had become the model for politically organizing the life of peoples. Towards 1900, three of the multi-ethnic European empires remained, but struggled as entities: the Habsburg Empire, the Russian (Tsarist) Empire, and the Ottoman Empire.

This was when the role of language and ethnicity started to shift: people started to think of themselves as speakers of distinct languages and members of distinct nationalities. The December Constitution of 1867 (valid for the Empire except Hungary) guaranteed Austrian citizenship, freedom of speech, and freedom of press, and was in fact so modern that these laws on the rights of citizens are still in force. Considering the circumstances of free speech and a free press, authorities were faced with two very 
popular movements within the empire: the Hungarian struggle for independence and Pan-Slavism. The Austro-Hungarian Compromise of 1867 was a concession to the Hungarians who had started to emancipate themselves from the Austrian Empire and wanted to eliminate foreign influence on their own terms. The Compromise created the state of Austria-Hungary on a legal basis and guaranteed the Hungarians their own parliament, their own representatives, and their own government.

By the end of the nineteenth century, however, Slavs in the Habsburg Empire (Slovenes, Croats and Serbs) had started to feel suppressed by the omnipresence of German (and Hungarian in the Hungarian half) in bureaucracy, administration, and higher education (e.g. universities). Only compulsory education was provided in the local languages, which led to discontent amongst Slavic members in the empire. Pan-Slavism gained popularity amongst many Slavic inhabitants who wanted equality with the Hungarian and Austrian halves of the empire. A culmination of this uprising conflict was the so-called Badeni-crisis of 1897 , which is important to mention because it indicates a process of nationalization within the empire, thus illustrating what Hobsbawm meant with the end of the "Age of Empire" (1989). In 1897, the Austrian prime minister, Count Badeni, declared that Czech would, like German, be an official language within the inner administration of Bohemia. Czech had already been an official language for the outer service, e.g. citizens had the right to get help in their own native language, and it was already a standardized literary language in the nineteenth century. Furthermore, Badeni declared that, in the future, only those who spoke both German and Czech fluently could serve as clerks in Bohemia. This was not a problem for the clerks of Bohemian origin since most of them grew up bilingual anyway. Protests came from the German-speaking clerks who feared that they would lose their predominance. Riots erupted and were so severe that even martial law had to be declared. By the end of 1897, Count Badeni resigned from office and his language decree was later repealed, leaving Czechs as well as Germans disappointed (Vocelka, 2000, pp. 248250). Unexpectedly, the political elites had to deal with the fact that people were no longer satisfied with serving the emperor and the empire. They wanted to express themselves as members of different national societies under the common rule of the House of Habsburg. This is the context within which the advancement of the nationstate concept in Austria in the following decades can be understood.

\section{Bourgeois elite, educational borrowings, and doing nation}

Based on the concept of "doing gender" (Butler, 1993), wherein a gender identity is socially constructed through actions and language (Gildemeister, 2008), we understand national identity also as a social construction. In examining the actions and language that construes a national identity on a daily and institutional basis, a new and very influential category of understanding and seeing the world with its values, rules, and standards is created. Understanding doing nation as a performative act indicates the 
question about the people and the spaces wherein a certain understanding of the world is constructed through constantly repeating speech, non-verbal, and symbolic communication. Without these spaces, construing communication and normalizing a certain political practice, namely the nation, could not develop. In the case of doing gender, these spaces seem to be as old as humanity itself, whereas the construct of the nation-state is barely older than 200 years, raising the issue of how these spaces have been opened up in different contexts. The discourse about nationalism researched in European contexts has been overwhelmingly described as an elite discourse. More than only elite, the idea of nationalism seems to be intertwined with a certain social class: the bourgeoisie (Hechter, 1975). Hechter's work about internal colonialism and the anglicization of the Celtic fringe showed how new bourgeois communities emerged from British political, economic, and cultural incentives by imitating the social stratification of the center and hence restructuring the whole society (Hechter, 1975). It is also remarkable that the decline of empires, the emergence of nation-states, and the spread of a global bourgeoisie have occurred in parallel, namely during the twentieth century and both the nation-state and a bourgeois class formation derived from Western Europe (Dejung et al., 2019, p. 2). The case of the Ottoman Empire opens up an imperial, non-Western context to understand how the ideology of nationalism and a specific social stratum are connected and dependent on one another, and furthermore, how education was linked to the creation of that social stratum.

\section{The case of the Ottoman Empire}

To render the idea of a nation intelligible, new spaces had to be developed, and indeed, they were, to a large extent by educational institutions. The ways in which Ottoman society was absorbing ideas during the long nineteenth century coming foremost from Western Europe (Shaw \& Shaw, 1977) deserve special attention, as well as how a certain transformation of local structures was needed precisely for this absorption. At the same time, "these structures were shaped by, and often the result of, highly uneven power relations," for instance, "imperialism and the emergence of a global economy that was increasingly dominated by Western Europe during the long nineteenth century" (Dejung et al., 2019, p. 4). It is here that "the rise of middle classes in Asian and African colonies was undoubtedly fueled by European imperialism, yet their emergence was shaped not only by Western influences but also by local conditions" (Dejung et al., 2019, p. 4). Within the Ottoman context, we can observe a tentative edging towards a changed society. The worldwide circulation of people, ideas, and goods (Dejung et al., 2019, p. 2) became institutionalized in the Ottoman Empire through "policy-useful knowledge" (Cowen, 2011).

Educational institutions - the first so-called secular schools - found their way into Ottoman society through military borrowings as early as in the 1830s. The Ottomans, aware of their military defeats against the Russians and the accompanying territorial losses, searched for best practices to reform their military and render it competitive 
again against the European powers. Influenced by the convincing victories in the 1820s by the Egyptian governor Muhammad Ali, who reorganized his provincial army with French consultation, the military reforms of Sultan Mahmud II also followed the French model (Reed, 1951) and was later supplemented by Prussian elements. In the course of Prussian counselling, first by the famous Prussian general Heinrich von Moltke between 1836-1839, and later in the 1880s by field marshal Colmar von der Goltz (Osterrieder, 2016, p. 60), military academies and curricula were adopted by the Ottoman government, underpinning the coupling of military and education within the formation of national minds (Boser, 2016, p. 5). Political movements like the Young Ottomans and later on the Young Turks consisted of people who had been educated in these new institutions - a new elite, ready to absorb and reproduce the ideology of nationalism (Mardin, 1997, p. 117). Even if nationalistic sentiments were not the exclusive reaction of those graduates (Fortna, 2002, p. 21), they discussed their ideas and visions on the political future of their empire in a very bourgeois manner: newspapers, periodicals, theatres, coffee houses, novels, etc. From the 1840s onwards, the display of a certain lifestyle, until then unknown or at least not very common in the empire: with a certain understanding of the world, the right moral behavior, the values to be followed and even the proper way to dress, to reside and spend leisure time, did not differ so much from their European counterparts in London, Paris or Berlin (Mestyan, 2019, p. 209; Motadel, 2019, p. 234).

For this "bourgeois universe of values," education obviously played a crucial role since it was regarded as being the main means to progress, personal achievement, self-perfection, and an individual personality coupled with a certain understanding of religion, politics, and science (Dejung et al., 2019, p. 10). The scope of educational borrowings from Western Europe in the course of the political reform era known as Tanzimat, from 1839 onwards (Can, 2013), lay in the emergence of a bourgeoisie equipped with another epistemological background (Göcek, 1996, p. 124). This class had a strong commitment to the idea that, through education, the problems of the empire "ranging from those of economic and military competitiveness, to those relating manpower, social control, cultural identification, and political loyalty" could be solved, if not entirely, then at least in large parts (Fortna, 2002, p. 30).

The emergence of that new social class can be observed on the basis of societal transformation processes in the empire. The organizational structure of the Ottoman Empire got successively undermined, when one of its main pillars, namely the household, was deeply shaken by military and educational reforms. A particularly impressive expression of this is the destruction of the so-called Janissary corps in 1826 through Sultan Mahmud II, representing an important shift in Ottoman statecrafting towards a centralized state that was able to impose its rule directly without imperial state intermediaries. The Janissaries - elite infantry units dating back to the fourteenth century who formed the Ottoman Sultan's household troops and bodyguards, and who were arguably the first modern standing army in Europe, having 
developed from a military unit into an influential social and political power within the empire - understandably opposed the Sultan's reforms. Bereaving these social agents of their power opened up space for new agents more willing to correspond with the modernizing and westernizing agenda of the Ottoman state.

By introducing Western-style schools, adopting Western furniture and receiving Western literature and arts, living spaces were transformed and so was the social space, identities, and hierarchies within the "imperial family". The symbols of power, recognition, and respect reflected this transformation explicitly since they also underwent an adjustment. An example of this is, that for centuries socialization and public display of wealth had occurred in the two stream valleys on the Bosphorus. In the course of the nineteenth century this changed in favor of the Pera district - a place inhabited mostly by Ottoman Christians who now set the tone for the latest fashion deriving from France (Quataert, 2005, p. 155).

Educational policies of the Ottoman state also displayed the shift from an imperial, family-based self-image to a more national, modern state centered self-understanding. Once begun with the destruction of the Janissaries the household was also removed from the "locus of education" in favour of an increasingly centralized and standardized modern state, thus firstly separating family from state, and secondly demonstrating the primacy of the state (Fortna, 2002, p.234). Here too, best practices and borrowed policies played a crucial role: Ottoman educational efforts began mostly as a reaction to the well-established schooling systems of Ottoman minorities and missionaries growing rapidly in number after the Imperial Reform Edict of 1856 . The Ministry of Education was founded in 1857, but real progress towards a more systematized and state-centered primary schooling system was only achieved through the Education Rescript of 1869 (Evered, 2012, p. 1). The French education minister, Victor Duruy, mainly counselled the Ottoman government in 1867 (Somel, 2001, p. 86), hence the Ottomans more or less copied the French curriculum, even though in the course of the implementation process, many local adaptations occurred (Cicek, 2012, p. 225). Through such a school system, Ottoman officials sought to create a connecting Ottoman identity under their dangerously diverging population (Evered, 2012, p. 2). But the statement of an Ottoman physician in the 1920s underscores that modern schooling had had another, completely unintended effect, namely the emergence of separate national identities:

We saw that a Circassian club had opened in our neighborhood. Then an Albanian association was formed. Soon after, an Arab philanthropic society appeared! [...] Circassians wanted their freedom, as did the Albanians. The members of all these clubs were graduates of our own schools. [...] Hence the Bulgarian [...] Albanian [...] Arab independence movements were all manned by those reared and educated in our country, our schools. (Nur, 1927/1967, p. 268; transl. KM) 


\section{The case of the Habsburg Empire}

Like in the Ottoman Empire, the Habsburg Empire and its developing bureaucracy from the eighteenth century on, were dependent on the approval of and cooperation with the social, political, and economic elites, usually the bourgeois middle and upper classes. Often, well-educated members of these social classes served as clerks and officers in the various regions of the empire. Social prestige, economic wealth, and personal acquaintances with other important members of society played a major role in one's career. Also important were one's loyalty and devotion to the House of Habsburg, not necessarily one's origins. Many contemporaries referred to the nineteenth and twentieth centuries as a golden age of humankind for those who enjoyed economic wealth and political freedom in the Habsburg Empire, as Stefan Zweig (1881-1942) mentions in his autobiography "The World of Yesterday" (1985). Emphasis was laid on one's merit, but rarely on one's nationality, since the concept of nation was rather young (it had started to emerge only at the end of the eighteenth century) and was only beginning to spread amongst the inhabitants of the empire.

The educational system as well as other aspects of social and public life in the Habsburg Empire were characterized by the neo-absolutism of Emperor Franz Joseph in the aftermath of the revolutions of 1848-49. Franz Joseph was not willing to accept various peoples' claims for more rights. One could argue that the role of the emperor was so dominant that it overlaid the national ambitions of the empire's ethnicities. Franz Joseph had become a symbol of Habsburg rule and secured his peoples' loyalty. Here, the relationship between the old empires and the succeeding nation-states becomes quite clear. Therefore, it is time to think about when and how the concept of nation came into play and united with the state, leading to the predominant concept of the nation-state.

In 1882, Ernest Renan asked in his famous talk about "What is a nation?" why Austria is a state, but not a nation (Renan, 1882, p. 10). Almost 140 years later, we can read in the opening line of an article published by the Austrian Broadcasting Corporation, "nobody would argue that Austria is a 'culture-nation"' (Baryani, 2020; transl. FG). In contrast, in 1996, Austria's 1000th birthday was celebrated: postage stamps were printed, anniversary coins sold and the like, but in fact, one can hardly say that Austria has existed since 996, the year the name Austria (Ostarrichi) was mentioned in a written document for the first time. One cannot help but consider that the celebrations were invented for tradition (Hobsbawm \& Ranger, 1983; Anderson, 1983). Obviously, in the times of the huge multi-cultural, multi-lingual, and multi-denominational Habsburg Empire, Austria was hardly considered a unified nation, whereas nowadays, the concept of an Austrian nation seems so self-evident that it is hardly ever questioned. But the "Austrians" self-assurance of being their own distinctive nation required hard work. So how did that happen?

If Austria is a nation(-state), there must be something like an awareness of having an Austrian nationality (as a cultural thesis of a "we") amongst the inhabitants of Austria. 
Indeed, we can see that, back in the long nineteenth century, the term Austria(n) was mainly used by the administration for the non-Hungarian half of the empire (another name was Cisleithania, deriving from the river Leitha, which delineated the border between the west of the Kingdom of Hungary and the rest of the Austro-Hungarian Dual-Monarchy). One must not confuse the term Austria of 1918 and afterwards with what this term stood for before 1918. The term "Austria" was used for all territories of the Habsburg Monarchy except for Hungary. For example, the constitution of 1867 contained a bill of rights for the citizen and granted Austrian citizenship to all inhabitants of the Habsburg Empire except for the Kingdom of Hungary which gave its inhabitants Hungarian Citizenship. Austrian citizens could be Ukrainians from Lviv, Czechs from Prague or Croats from the south of the empire. Neither language nor ethnicity tied them together, but their citizenship and belonging to the Habsburg Monarchy did. In the core of the monarchy lay what would later be Austria, and the question is: People in the monarchy considered themselves Austrian citizens, but did they consider themselves part of a particular nation? Most interestingly, they barely considered themselves national Austrians, instead they thought of themselves as Germans, not only during the monarchy, but also afterwards when the Republic of German-Austria was founded in 1918 and renamed as Republic of Austria in the wake of the Treaty of Saint-Germain-en-Laye in 1919. A geography textbook used in middle schools during the monarchy can illustrate an example of this. Here, we can read the following on Austria-Hungary: "The population is mixed and consists of Germans, Slavs [...] Magyars and Romances" (Weingartner, 1918, p. 52; transl. FG). The Austrian lands/duchies are presented one after another: " 1 . The Archduchy of Austria below the Enns [...] counts 2 million people. [...] The population is German. 2. The Archduchy of Austria above the Enns [...] Population German. 3. The Duchy of Salzburg [...] Population German" (Weingartner, 1918, p. 52; transl. FG). This feeling of being German and belonging to the German people and nation continued after the dissolution of the monarchy. A textbook for fatherland studies (Vaterlandskunde) from 1923 presents the population of the Republic of Austria as such: "With the exception of Burgenland and of Carinthia, the population of all federal states is more than $95 \%$ German, so they are mere German settlement areas" (Goll, 1923, p. 38; transl. FG).

One could ask why the Austrians call themselves Germans, and why the orientation of the inhabitants of the later Austrian Republic had not changed when politics made a sharp turn from the Habsburg monarchy to democracy. After the First World War, very strict laws on the nobility and the House of Habsburg were applied: titles of nobility were abolished, the Habsburgs lost all their properties, and had to leave the country: the Emperor and his family returned to Switzerland in March 1919 after more than 650 years of Habsburg rule. The new republic did not hesitate to make new laws and a new constitution, but - surprisingly or not - this hardly affected the sphere of school and education. As we could see above, children attending school in 1923 read in their textbooks that ethnic Germans inhabited their homeland, just as they learnt before 
1918. They now lived in Austria, but they were taught to consider themselves nationally as Germans, just like their ancestors. Furthermore, in fatherland studies, children not only learned that in their new homeland of Austria lived the Germans of the former Habsburg Empire, but that they also had to leave behind their German kinsmen who were not allowed to join a German state and now lived in other successor countries of the former Habsburg Empire (e.g. Hungary, Czechoslovakia). Consequently, we can read in the previously cited textbook for fatherland studies: "While German-Austria received only 5,787.193, that is more than the half of the Germans of Old Austria, the nationstates received 4,163.461 Germans of the old state" (Goll, 1923, pp. 38-39; transl. FG).

What had gone wrong here? Or rather, why did the newly founded Austria not act like other nation-states and emphasize stronger ideas of national identity when, during the long nineteenth century, they gave themselves constitutions and then consistently enacted new school legislation in order to implement their ideas of identity and social order inherent in the constitutions? The reason for this is that the concept of an independent Austrian nation-state was promoted as a model by the Allies in general and France in particular, and it aimed at weakening the Germanspeaking area in Europe. The Republic of German-Austria, in 1918, had been founded by the German-speaking representatives of the former parliament (Reichsrath), but was renamed as Republic of Austria, after the Allies had prohibited the unification of Austria with Germany. By that time, the Allies applied, or better, enforced, their pattern of a nation-state on a territory that had never been designed to be a distinct nation, let alone a nation-state. Austria was now forced to consider itself as a nationstate, but, unfortunately, Austrians themselves did not know about that. In contrast, they struggled for unification with Germany from the moment the monarchy ceased to exist, calling their new homeland, which they considered part of the new Germany, in 1918, German-Austria (Deutschösterreich). At first, nobody really seemed to care about that, but when the negotiations in Paris started in 1919, the Allies made their point clear and the delegates of German-Austria had to change the country's name to Austria or face the threat of occupation. German-Austria took the order and changed its constitution and its name. Austria was created, but lacked Austrians, who now had to be made basically out of nothing (distinct).

To make Austrians loyal to the new nation-state meant, first, a genuine Austrian identity would be necessary, a vision of what makes Austrians unique. But this vision did not exist in particular as a fitting model of a sovereign democratic Austria in its shape from 1918 onwards. Neither school nor politics nor elites tried to create an ideal vision of an Austrian society within the forced political borders of Austria. Austrian politicians and people rather blamed the Allies for tearing apart the German people and the German nation by enforcing an Austrian state that should understand itself as a nation-state. While the Germans in the other successor states of the Habsburg empire kept their feeling of belonging to the German nation, like the Sudeten Germans (Sudetendeutsche) - who ironically had in fact belonged to the Austrian monarchy, but 
were "taken home" into the Third Reich, to which they had never belonged, in 1938, this was no long term option for the Austrian Germans. We only see a slight change in the attitude towards the Republic of Austria as a nation-state by the end of the 1920s and even stronger from the beginning of the 1930s on, when - in a comparative view a large part of the former Ottoman Empire had already been turned into the Republic of Turkey by a nationalist movement. In the Republic of Austria, a similar nationalist movement did not exist at that time. It can be presumed that the developing dictatorship of chancellor Dollfuß was the first extensive attempt to create a genuine Austrian identity distinct from the German Empire and the Third Reich later on. His attempt was still based on the German-ness of Austrians, but it was a superior German-ness mainly based on culture (Buchmann, 2019, pp. 159-160). Unlike the main successor of the Ottoman Empire, the Turkish Republic as the Turkish nation-state, the First Republic of Austria lacked a genuine, distinct new epistemology, but was trapped between the glory of the Habsburg Empire and the claim of being German on the one hand, and the new republic's self-consciousness and forced sovereignty on the other hand.

\section{Conclusion}

As we can see, nationalism and the idea of the nation-state faced the Ottoman and Habsburg Empires with various challenges throughout the nineteenth and twentieth centuries. Despite all that the two empires had in common, their social stratification and political self-images differed largely from each other. Whereas the Habsburg Empire had already an aristocratic and bourgeois elite and an existing schooling system since Maria-Theresia embedded it in the existing imperial system, the Ottoman Empire did not consist of social classes but organized itself instead in households comprising the vast range of social classes. Its religious heterogeneity was organized according to the millet system, granting the Jewish, Armenian, and Greek millets a semi-autonomous status on its territory, thereby balancing ethnic, linguistic, and cultural affiliations by religious alignment. Education in the Ottoman Empire was not regarded as a field to be interfered by the state, thus it was left, in the case of its minorities, to the millets themselves, to the private education within the households, or to the religious establishments that had already developed religious educational schooling, known as a madrasa system. But things changed dramatically for the Ottomans when the ideology of nationalism literally gained ground on its territory after stemming from the Balkans. In contrast to the elites of the Habsburg Empire, who regarded themselves as German, the Ottoman officials did not have an understanding of themselves as a specific nation. Indeed, the Ottoman state had been through and through ,anational“ (Karpat, 2001, p. 286). The active demarcations of their minorities as distinguished peoples, forced the otherwise a-national Ottoman state into the search for a common identity, capable of stopping the erosion of the Empire. A centralized schooling system based on the model of France was regarded as the best means to establish „Ottomanism“ and harmonize the ethnic unrest within the empire. But since Ottomanism could not really refer to existing and established identities, like religious, ethnic, or linguistic ones, and since 
the Great Powers championed the secession claims of Ottoman minorities due to their imperial interests, the way was soon paved for Turkish nationalism.

The Austro-Hungarian Empire, on the other hand, quite early experienced the power of nationalism and what it meant for a multi-ethnic empire to suffer from inner friction between several nationalities in the process of their creation. Nevertheless, the elites of the empire lacked the will for and the vision of a genuine Austrian identity that would have been different from their German neighbors. They missed the train, while many other states in Europe started to link their institutions and people with the nation according to the French ,winning " model. It then turned out to be too late for them, when the German-minded core of the Austro-Hungarian monarchy was catapulted into the Age of Nation-states after the First World War.

These two examples have explained how different the ways of dealing with new ideas in the "same" context of a multi-ethnic and multi-lingual empire could develop. After the First World War, both empires were to be reduced to a minimal torso. But whereas the Habsburg Empire was politically forced to - although unsuccessfully - adjust itself to the idea of a nation, the Treaty of Sèvres in 1920 fueled Ottoman resistance and led to a war for independence against the allies that culminated in the emergence of the Turkish republic. Therefore, both cases elucidate how the travel of a specific Western European idea, namely that of the nation-state, occurred either by imposing it forcefully or, as the Ottoman case shows, by political and institutional borrowings that, within a century, successively changed an imperial elite into a national one by means of a centralized and standardized schooling system. The „long nineteenth century“ began with the transformation of the French Ancien Régime to the French nationstate and ended with the establishment of the nation-state as the predominant model of governance in Europe and beyond. Heterogeneous empire-states with centuries old experience in governing diversity could not assert themselves against the French-made political formation of a nation-state. The twentieth century has undoubtedly marked the sidereal hour of the French nation-state, which has been exported and imported - forcefully and willingly -, changed, adjusted, modified, and altered according to local contexts. Nevertheless, newer research on „state-nations" more able to cope with diversity, ambiguity, and hybrid identities (Stepan et al., 2010) render the imperial model from a discontinued one to a very up-to-date model worth digging deeper into.

\section{References}

Ahmad, F. (1993). The Making of Modern Turkey. Routledge.

Anderson, B. (1983). Imagined Communities: Reflections on the Origin and Spread of Nationalism. Verso Editions.

Aymes, M. (2015). Defective Agency. In M. Aymes, B. Gourisse, \& È. Massicard (Eds.), Order and Compromise: Government Practices in Turkey from the Late Ottoman Empire to the Early 21st Century (pp. 25-44). Brill. https://doi.org/10.1163/9789004289857_003 
Barkey, K. (2008). Empire of Difference. The Ottoman in Comparative Perspective. Cambridge University Press. https://doi.org/10.1017/CBO9780511790645

Baryani, F. (2020). Die Wiedererfindung der "Kulturnation" [The reinvention of the "culturenation"]. https://orf.at/stories/3166707/

Boser Hofmann, L. (2016). Nation, Nationalism, Curriculum, and the Making of Citizens. In M. A. Peters (Ed.), Encyclopedia of Educational Philosophy and Theory (pp. 1-6). Springer Nature.

Bouquet, O. (2015). Is It Time to Stop Speaking about Ottoman Modernisation? In M. Aymes, B. Gourisse, \& È. Massicard (Eds.), Order and Compromise: Government Practices in Turkey from the Late Ottoman Empire to the Early 21st Century (pp. 45-67). Brill. https:// doi.org/10.1163/9789004289857004

Buchmann, B. M. (2019). Insel der Unseligen. Das autoritäre Österreich 1933-1938 [Island of the Unfortunates. Authoritarian Austria 1933-1938]. Molden.

Can, İ. (2013). Türk Ulusal Kimliğinin İnşasında Milli Eğitim İdeolojisinin Rolü [The Role of the Ideology of National Education in the Construction of Turkish National Identity]. Sosyoloji Divanı Dergisi, 1(1), 123-147.

Cicek, N. (2012). The Role of Mass Education in Nation-Building in the Ottoman Empire and the Turkish Republic, 1870-1930. In L. Brockliss \& N. Sheldon (Eds.), Mass Education and the Limits of State Building c. 1870-1930 (pp. 224-250). Palgrave Macmillan. https:// doi.org/10.1057/9780230370210 10

Cowen, R. (2011). Edging closer to the hero, the barbarian, and the stranger. A note on the condition of comparative education. In D. Tröhler \& R. Barbu (Eds.), Education Systems in Historical, Cultural, and Sociological Perspectives (pp. 21-36). Sense Publishers. https:// doi.org/10.1007/978-94-6091-827-8 3

Dejung, C., Motadel, D., \& Osterhammel, J. (2019). Worlds of Bourgeoisie. In C. Dejung, D. Motadel, \& J. Osterhammel (Eds.), The Global Bourgeoisie. The Rise of the Middle Classes in the Age of Empire (pp. 1-40). Princeton University Press.

Erimntan, C. (2008). Ottomans Looking West? The Origins of the Tulip Age and its Development in Modern Turkey. I.B. Tauris. https://doi.org/10.5040/9780755610013

Evered, E. Ö. (2012). Empire and Education in the Ottoman Empire: Politics, reforms and resistance from the Tanzimat to the Young Turks. I.B. Tauris. https://doi.org/10.5040/9780755607723

Fortna, B. C. (2002). Imperial Classroom. Islam, The State, and Education in the Late Ottoman Empire. Oxford University Press.

Gildemeister R. (2008). Soziale Konstruktion von Geschlecht: „Doing Gender“ [The Social Construction of Gender: „Doing gender“]. In S. M. Wilz (Ed.), Geschlechterdifferenzen - Geschlechterdifferenzierungen [Gender Differences - Gender Differentiations] (pp. 167198). VS Verlag für Sozialwissenschaften. https://doi.org/10.1007/978-3-531-90831-1 6

Göçek, F. M. (1996). Rise of the Bourgeoisie, Demise of Empire. Ottoman Westernization and Social Change. Oxford University Press. https://doi.org/10.1093/acprof:oso/9780195099256.001.0001

Goll, K. (1923). Die Republik Österreich. Ein Behelf für den Unterricht in der Vaterlandskunde [The Republic of Austria. A makeshift for the education in fatherland studies]. Österreichischer Schulbuchverlag. 
Gourisse, B. (2015). Order and Compromise. The Concrete Realities of Public Action in Turkey and the Ottoman Empire. In M. Aymes, B. Gourisse, \& È. Massicard (Eds.), Order and Compromise: Government Practices in Turkey from the Late Ottoman Empire to the Early 21st Century (pp. 1-24). Brill. https://doi.org/10.1163/9789004289857 002

Harp, S. L. (1998). Learning to be loyal. Primary schooling as nation building in Alsace and Lorraine, 1850-1940. Northern Illinois University Press.

Hechter, M. (1975). Internal Colonialism. The Celtic Fringe in British National Development, 1536-1966. University of California Press.

Hobsbawm, E. J. (1989). The Age of Empire: 1875-1914. Vintage Books.

Ichijo, A. (2013). Nationalism and Multiple Modernities. Europe and Beyond. Palgrave Macmillan. https://doi.org/10.1057/9781137008756

Inalcik, H. (2014). Devleti Aliyye. Osmanlı İmparatorluğu Üzerine Araştırmalar 2. Tagaffür ve Fesad (1603-1656). Bozulus ve Kargaşa dönemi [The Sublime State. Research on the Ottoman Empire 2. Era of Decay and Confusion]. Türkiye Is Bankasi Yayinlari.

Karpat, K. H. (2001). Politicization of Islam. Reconstructing Identity, State, Faith, and Community in the Late Ottoman State. Oxford University Press.

Lewis, B. (2002a). The emergence of Modern Turkey. Oxford University Press.

Lewis, B. (2002b). What went wrong? Western Impact and Middle Eastern Response. Oxford University Press.

Mardin, S. (1997). The Ottoman Empire. In K. Barkey \& K. von Hagen (Eds.) After Empire. Multiethnic Societies and Nation-Building. The Soviet Union and the Russian, Ottoman, and Habsburg Empires (pp. 129-141). Westview Press.

Meeker, M. (2001). A Nation of Empire. The Ottoman Legacy of Turkish Modernity. Berkeley \& University of California Press. https://doi.org/10.1525/9780520929128

Mestyan, A. (2019). The Muslim Bourgeoisie and Philanthropy in the Late Ottoman Empire. In C. Dejung, D. Motadel, \& J. Osterhammel (Eds.), The Global Bourgeoisie. The Rise of the Middle Classes in the Age of Empire (pp. 207-228). Princeton University Press. https://doi. org/10.23943/princeton/9780691177342.003.0010

Motadel, D. (2019). Worlds of a Muslim Bourgeoisie the sociocultural milieu of the Islamic Minority in Interwar Germany. In C. Dejung, D. Motadel, \& J. Osterhammel (Eds.), The Global Bourgeoisie. The Rise of the Middle Classes in the Age of Empire (pp. 229-250). Princeton University Press. https://doi.org/10.2307/j.ctvhrd124.16

Nur, R. (1927/1967). Hayat ve Hatiratim [My Life and my Memories]. Altindag Yeyinevi.

Osterrieder, M. (2015). Von Berlin nach Konstantinopel. Helmuth von Moltke, Colmar von der Goltz und das Osmanische Reich - Teil I. [From Berlin to Constantinople. Helmuth von Moltke, Colmar von Goltz and the Ottoman Empire]. Die Drei Zeitschrift für Anthroposophie in Wissenschaft, Kunst und sozialem Leben. 6, 55-65.

Özkırımlı, U. (2010). Theories of Nationalism: A critical introduction ( $2^{\text {nd }}$ rev. \& ext. ed.). Palgrave Macmillan.

Quataert, D. (2005). The Ottoman Empire 1700-1922. Cambridge University Press. https:// doi.org/10.1017/CBO9780511818868 
Renan, E. (1882, March 11). What is the nation? [Paper presentation]. Conference faite at Sorbonne (Paris, France). Calmann Lévy.

Reed, H.R. (1951). The destruction of the Janissaries by Mahmud II in June, 1826. Princeton University Press.

Shaw, S., \& Shaw, E. K. (1977). History of the Ottoman Empire and Modern Turkey. Volume 2. Reform, Revolution, and Republic: The Rise of Modern Turkey 1808-1975. Cambridge University Press. https://doi.org/10.1017/CBO9780511614972

Smith, A. D. (2009). Ethnosymbolism and Nationalism. A cultural approach. Routledge.

Somel, S. A. (2001). The Modernization of Public Education in the Ottoman Empire, 1839-1908. Islamization, Autocracy and Discipline. Brill.

Stepan, A., Linz, J. J., \& Yadav, Y. (2010). The Rise of “State-Nations”. Journal of Democracy, 21(3), 50-68. https://doi.org/10.1353/jod.0.0187

Tröhler, D. (2020). National literacies, or modern education and the art of fabricating national minds. Journal of Curriculum Studies, 1-17. https://doi.org/10.1080/00220272.2020.1786727

Vocelka, K. (2002). Geschichte Österreichs. Kultur - Gesellschaft - Politik [History of Austria. Culture - Society - Politics] (7 ${ }^{\text {th }}$ ed.). Wilhelm Heyne.

Weber, E. (1979). Peasants into Frenchmen. The Modernization of Rural France 1870-1914. Chatto \& Windus.

Weingartner, L. (1918). Grundzüge der Erdbeschreibung. für die erste Klasse der Mittelschulen [Outlines of geography. for the first class of middle school] ( $4^{\text {th }}$ ed.). Manzsche k. u. k. Hof-, Verlags- und Universitätsbuchhandlung.

Zweig, S. (1942/1985). Die Welt von gestern. Erinnerungen eines Europäers [The World of Yesterday. Memories of a European] ( $4^{\text {th }}$ ed.). Fischer Taschenbuch.

\author{
Kevser Muratovic \\ Centre for Teacher Education \\ University of Vienna \\ Porzellangasse 4, 1090 Vienna, Austria \\ kevser.muratovic@univie.ac.at
}

\section{Florian Gimpl}

Centre for Teacher Education

University of Vienna

Porzellangasse 4, 1090 Vienna, Austria

florian.gimpl@univie.ac.at 


\section{Činjenje nacije u carstvima: pojava Turske i Austrije}

\section{Sažetak}

U ovom članku ispituje se izgrađivanje nacije u vezi s obrazovanjem i obrazovnim institucijama, na primjeru dva bivša velika aktera u europskoj politici nakon Prvog svjetskog rata: Otomanskog Carstvu i Habsburškog Carstva. Habsburško Carstvo promatra se prvenstveno kroz poseban fokus na udžbenike u 1918. godini i periodu nakon nje, usporedujući ih međusobno i razumijevajući ih kao glavne alate širenja nacionalnih ideja unutar državnih škola. Kako će biti pokazano, ideja austrijske nacije u smislu ideologije nacionalne države teško se može naći, kako prije, tako i neposredno nakon sloma 1918. godine. S druge strane, Otomansko Carstvo ispituje se kao primjer činjenja nacije u procesu transformacije društvenih struktura unutar ne-zapadnih društava, kroz škole zapadnjačkoga stila te stoga doprinosi nacionalnom ostvarenju Republike Turske. U ovom članku istražuju se imperijalne osnove ove dvije nacionalne države i način na koji su se one i prijašnja carstva bavili modernim konceptom nacije i nacionalizma.

Ključne riječi: Austrija; Habsburško Carstvo; izgradnja nacije; Otomansko Carstvo; Turska. 